TECHNICAL TRANSACTIONS 8/2018

MECHANICS

DOI: $10.4467 / 2353737$ XCT.18.125.8900 SUBMISSION OF THE FINAL VERSION: 3/08/2018

\author{
Łukasz Ślusarczyk (D) orcid.org/0000-0002-3565-7868 \\ slusarczyk@mech.pk.edu.pl \\ Emilia Franczyk \\ Institute of Production Engineering, Faculty of Mechanical Engineering, Cracow \\ University of Technology
}

\title{
EXPERIMENTAL DETERMINATION OF THE TEMPERATURE IN THE CUTTING ZONE DURING TURNING OF TITANIUM ALLOY GRADE 2
}

\author{
EKSPERYMENTALNE WYZNACZENIE TEMPERATURY W STREFIE SKRAWANIA \\ PODCZASTOCZENIA STOPU TYTANU GRADE 2
}

\begin{abstract}
The paper presents the laboratory measurements results of temperature distribution in the cutting zone during orthogonal turning of a GRDE 2 titanium tube. The cutting tool used during the tests was a bimetallic cut-off tool with an uncoated insert made of P10 sintered carbide. The test plan was developed using the MiniTab16 computer application and the Taguchi method. The tests were performed in accordance with orthogonal table L9, which describes nine cutting trials for two independent factors, cutting speed $v[\mathrm{~m} / \mathrm{min}]$ and feed rate $f[\mathrm{~mm} / \mathrm{rev}]$, at three different values. The temperature distribution in the cutting zone was measured by means of a FLIR SC 620 thermal imaging camera. The archiving and processing of measurement results was performed with the ThermaCamResearcher Pro 2.9 computer application. The obtained results were used to determine the average temperature for each of the nine trials; then, a statistical analysis of the results was performed.
\end{abstract}

Keywords: GRADE 2, temperature, thermovision camera

\section{Streszczenie}

Artykuł prezentuje wyniki badań laboratoryjnych pomiaru rozkładu temperatury w strefie skrawania podczas toczenia ortogonalnego rury ze stopu tytanu GRDE 2. Narzędziem skrawającym wykorzystanym podczas badań był przecinak bimetaliczny z niepokrywaną plytką z węglika spiekanego P10. Plan badań zbudowano przy pomocy aplikacji komputerowej MiniTab16, z wykorzystaniem metody Taguchi. Badania realizowano zgodnie z wyznaczoną tablicą ortogonalną L9, która opisuje wykonanie dziewięciu prób skrawnych dla dwóch niezależnych czynników, prędkości skrawania $v$. $[\mathrm{m} / \mathrm{min}]$ oraz posuwu $f[\mathrm{~mm} / \mathrm{obr}]$, przy ich trzech różnych wartościach. Rozkład temperatury w strefie skrawania był mierzony z wykorzystaniem kamery termowizyjnej FLIR SC 620. Archiwizację i opracowanie wyników pomiarów zrealizowano z wykorzystaniem aplikacji komputerowej ThermaCamResearcher Pro 2.9. Na podstawie uzyskanych wyników wyznaczono wartość średniej temperatury w strefie skrawania dla każdej z dziewięciu prób, następnie dokonano statystycznej analizy wyników.

Slowa kluczowe: GRADE 2, temperatura, kamera termowizyjna 


\section{Introduction}

CNC machine tools are now widely used in mass production. A huge emphasis is placed on the reduction of manufacturing costs. In machining, one of the factors that allows for a cost reduction is minimising the cutting tool wear $[1,10]$. The key issue in this regard is a correct choice of cutting parameters, which is particularly difficult in case of machining of titanium alloys, as these alloys have a low thermal conductivity coefficient and, in addition, they are cold-work hardened during the machining. These factors expose a cutting tool to an intensive wear $[2,3]$. One of the methods to extend the tool life is the optimisation of the cutting process: cutting speed, feed rate and cutting depth. This can be implemented through an experimental determination of the impact of individual cutting parameters on the wear intensity of the tool blade. The other method is the measurement of physical magnitudes during the machining, such as cutting force or temperature in the cutting zone $[5,7,9]$. A lot of attention is given in the literature to the contact and contactless temperature measurement in the cutting zone $[4,6,8]$. The contact methods use thermocouples installed in the vicinity of the cutting edge. These methods are relatively difficult to implement, or even impossible to use in industrial practice. The other method to measure the temperature in the cutting zone is the use of devices measuring the infrared radiation, pyrometers, and thermal imaging cameras. These methods are much easier to implement than the contact methods, and the obtained temperature values and distributions in the cutting zone allow for a verification of the correctness of the applied cutting parameters and machining process [3].

\section{Conducted research}

The laboratory tests were conducted on a stand, which, in addition to the cutting zone temperature measurement, also allows for the measurement of cutting forces and a recording of fast-changing images during the chip formation process. The test stand, where the temperature in the cutting zone was recorded, is shown in Fig. 1.

The workpiece was a tube made of titanium alloy GRADE 2, diameter $\mathrm{D}=60 \mathrm{~mm}$.

The chemical composition of the titanium alloy GRADE 2, according to the EN 10204-3.1 standards, is presented in Table 1.

Table 1. The percentage chemical composition of the titanium alloy GRADE 2

\begin{tabular}{|c|c|c|c|c|c|c|}
\hline & Fe & C & N & O & H & Ti \\
\hline GRADE 2 max. & 0.30 & 0.08 & 0.03 & 0.25 & 0.015 & Bal. \\
\hline
\end{tabular}

Some properties of the titanium alloy GRADE 2 are presented in Table 2.

The thermographic camera was placed in front of the machining zone. Table 3 presents the configuration parameters of the FILR SC 620 thermovision camera. 


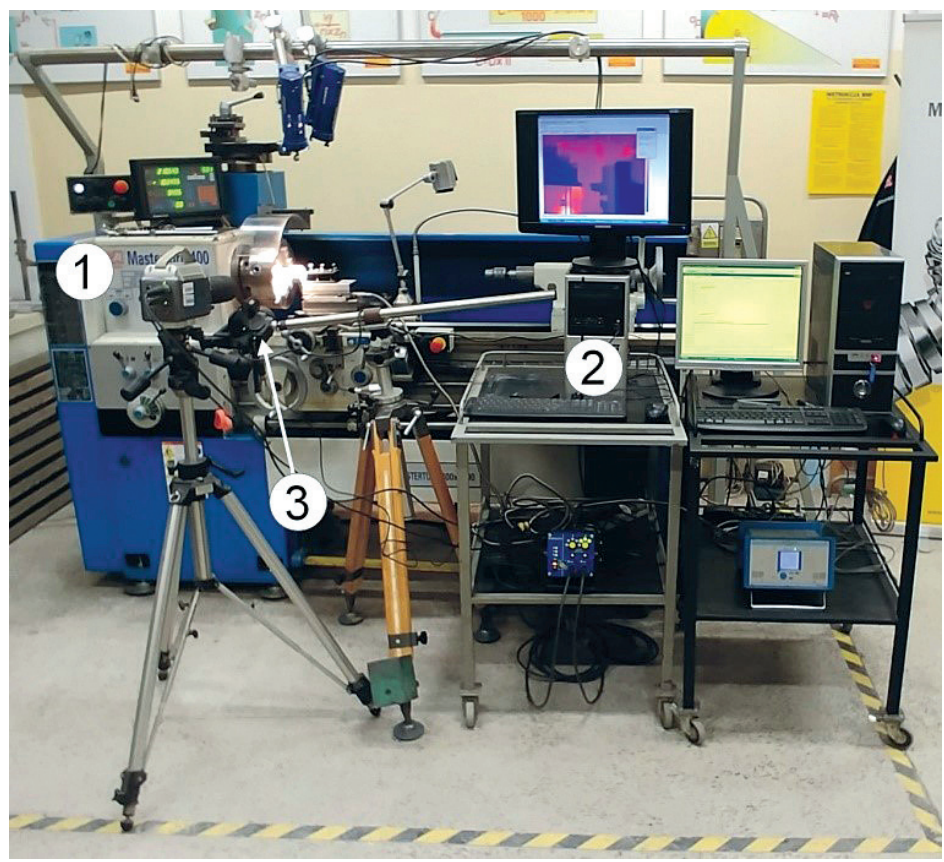

Fig. 1. The test stand where the temperature in the cutting zone was recorded. The compared measurement path consisted of:

1. a conventional turning machine Knuth Masterturn 400,

2. computer PC with ThermaCam Researcher 2.9 software, 3. thermovision camera FLIR SC 620.

Table 2. The properties of the titanium alloy GRADE 2

\begin{tabular}{|c|c|}
\hline Melting Point & ca. $1660\left[{ }^{\circ} \mathrm{C}\right]$ \\
\hline Density & $4510\left[\mathrm{~kg}^{*} \mathrm{~m}^{-3}\right]$ \\
\hline Modulus of Elasticity & $105[\mathrm{GPa}]$ \\
\hline Specific Heat Capacity & $526\left[\mathrm{~J}^{*} \mathrm{~kg}^{-1 *} \mathrm{~K}^{-1}\right]$ \\
\hline Thermal Conductivity & $16.4\left[\mathrm{~W}^{*} \mathrm{~m}^{-1 *} \mathrm{~K}^{-1}\right]$ \\
\hline
\end{tabular}

Table 3. The configuration parameters of the FILR SC 620 thermovision camera

\begin{tabular}{|c|c|c|}
\hline & ambient temperature & $22{ }^{\circ} \mathrm{C}$ \\
\hline
\end{tabular}


The cutting tool used during the tests was a bimetallic cut-off tool with a $5 \mathrm{~mm}$-wide uncoated insert made of P10 sintered carbide. The cutting insert had a flat face. In the tool coordinate system, the rake angle was $\gamma=10^{\circ}$, and the clearance angle was $\alpha=8^{\circ}$. The machining involved straight turning along the tube wall. Fig. 2 presents the tool position relative to the workpiece.

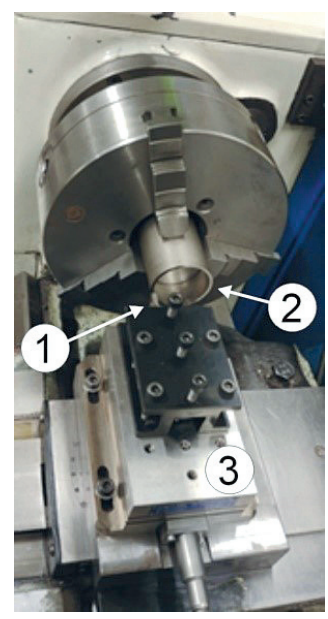

Fig. 2. The tool position relative to the workpiece, where:

1. single-position tool holder with insert installed,

2. a tube made of titanium alloy GRADE 2, diameter $\mathrm{D}=60 \mathrm{~mm}$,

3. a dynamometer mounted on the lathe slide.

The cutting parameters (speed and feed rate) were chosen according to the recommended datasheet values. The test plan, developed on the basis of the Taguchi method, involved nine trials. The cutting speed $v$, and feed rate $f$, were independent variables. The parameter values for the individual trials are given in the table below (Table 4). The cutting depth was identical to the tube wall thickness and it was the same in each trial - equal to $a_{p}=2.7 \mathrm{~mm}$.

Table 4. The parameter values for individual trials

\begin{tabular}{|c|c|c|c|c|c|}
\hline Test no. & A & B & $v_{c}[\mathrm{~m} / \mathbf{m i n}]$ & $f[\mathrm{~mm} / \mathbf{r e v}]$ & $a_{p}[\mathrm{~mm}]$ \\
\hline 1 & 1 & 1 & 60 & 0.048 & 2.77 \\
\hline 2 & 1 & 2 & 60 & 0.153 & 2.77 \\
\hline 3 & 1 & 3 & 60 & 0.249 & 2.77 \\
\hline 4 & 2 & 1 & 100 & 0.048 & 2.77 \\
\hline 5 & 2 & 2 & 100 & 0.153 & 2.77 \\
\hline 6 & 2 & 3 & 100 & 0.249 & 2.77 \\
\hline 7 & 3 & 1 & 140 & 0.048 & 2.77 \\
\hline 8 & 3 & 2 & 140 & 0.153 & 2.77 \\
\hline 9 & 3 & 3 & 140 & 0.249 & 2.77 \\
\hline
\end{tabular}


The maximum temperatures in the cutting zone during straight turning in each of the 9 trials were recorded by a thermovision camera and connected to a computer with the ThermaCAM Researcher 2.9 software installed. Exemplary frames with maximum temperature in the no. 1 and 2 trials are shown below (Fig. 3-4).

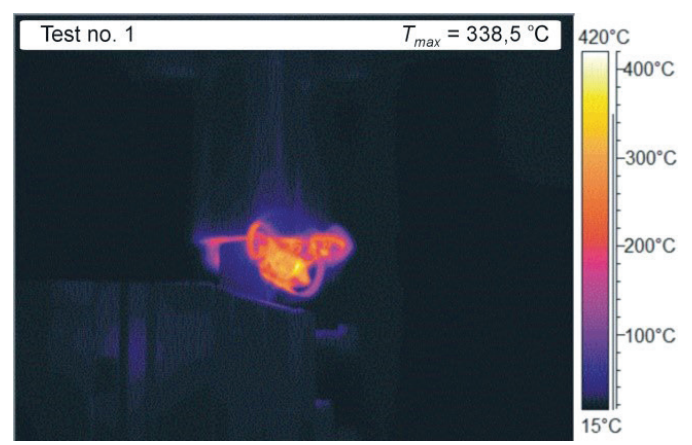

Fig. 3. Thermogram with maximum temperature during test no. 1

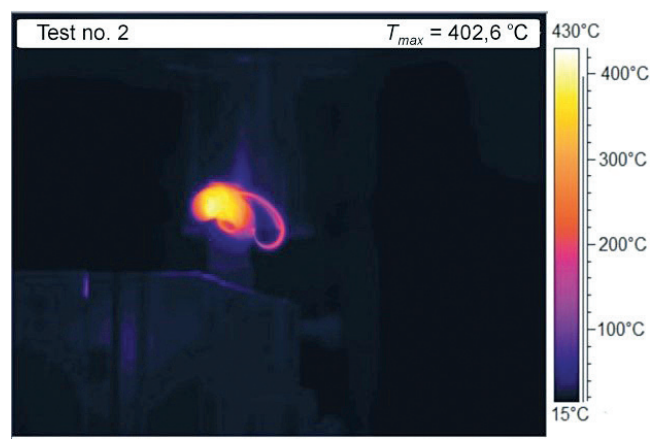

Fig. 4. Thermogram with maximum temperature during test no. 2

The data received from the software were also used to obtain the stabilised temperature values. Fragments of temperature curves (typical figures below Fig. 5 a) b)) were selected based on the stabilised maximum temperature curves for each trial in order to determine the average maximum temperature values.
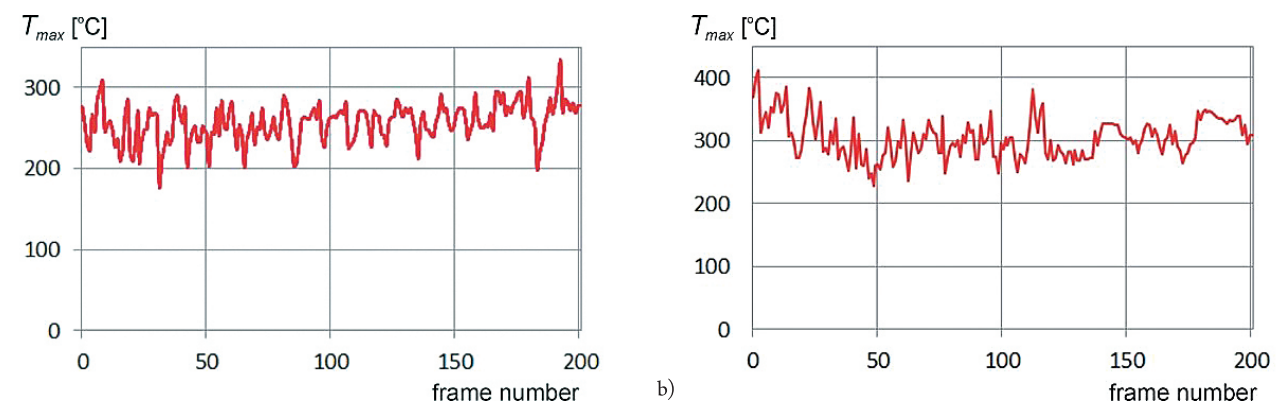

Fig. 5. The maximum temperature during the turning

a) test no. 1, b) test no. 2 


\section{Findings}

On the basis of the performed analysis, the average values of the maximum temperature were determined for each of the 9 tests (Fig. 6). Due to the variable values of cutting parameters $\left(v_{c} f\right)$, the stabilised temperature waveforms were characterised by different amplitudes.

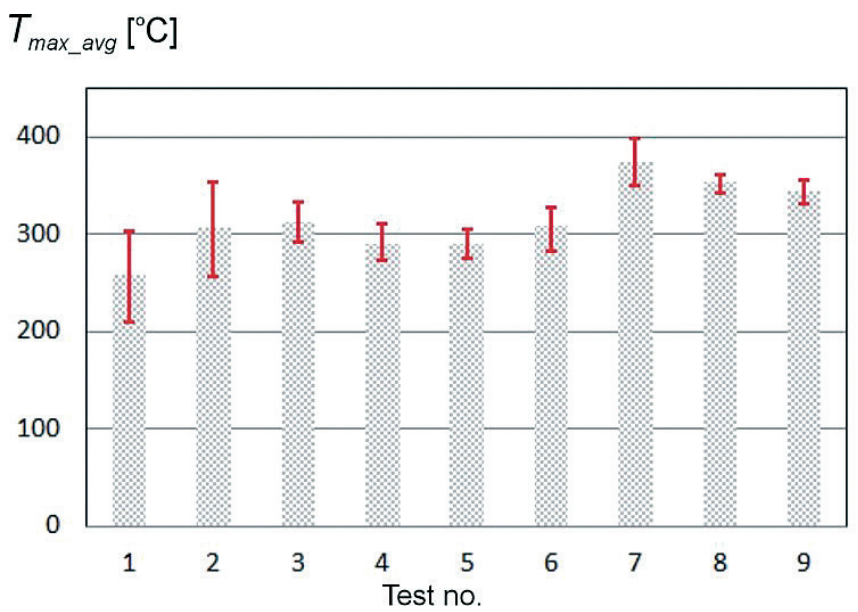

Fig. 6. Average values of the maximum temperature for each of the 9 tests

Table 5 below includes the average maximum temperature values.

Table 5. The average maximum temperature values

\begin{tabular}{|c|c|c|c|c|c|c|c|}
\hline $\mathrm{A}$ & $\mathrm{B}$ & $\begin{array}{c}v_{c}[\mathrm{~m} / \\
\mathrm{min}]\end{array}$ & $\begin{array}{c}f \\
{[\mathrm{~mm} /} \\
\mathrm{rev}]\end{array}$ & $\begin{array}{c}T_{\max -1} \\
{\left[{ }^{\circ} \mathrm{C}\right]}\end{array}$ & $\begin{array}{c}T_{\max -2} \\
{\left[{ }^{\circ} \mathrm{C}\right]}\end{array}$ & $\begin{array}{c}T_{\max 3} 3 \\
{\left[{ }^{\circ} \mathrm{C}\right]}\end{array}$ & $\begin{array}{c}T_{\text {max } \text { avg }} \\
{\left[{ }^{\circ} \mathrm{C}\right]}\end{array}$ \\
\hline 1 & 1 & 60 & 0.048 & 210.3 & 257.2 & 303.6 & 257.0 \\
\hline 1 & 2 & 60 & 0.153 & 256.5 & 309.9 & 353.3 & 306.7 \\
\hline 1 & 3 & 60 & 0.249 & 291.6 & 308.6 & 332.1 & 310.8 \\
\hline 2 & 1 & 100 & 0.048 & 272.4 & 286.4 & 309.9 & 289.6 \\
\hline 2 & 2 & 100 & 0.153 & 274.9 & 286.5 & 305.0 & 288.9 \\
\hline 2 & 3 & 100 & 0.249 & 283.4 & 311.2 & 327.2 & 307.3 \\
\hline 3 & 1 & 140 & 0.048 & 350.0 & 371.0 & 399.1 & 373.3 \\
\hline 3 & 2 & 140 & 0.153 & 342.0 & 357.4 & 361.1 & 353.5 \\
\hline 3 & 3 & 140 & 0.249 & 330.4 & 343.3 & 356.0 & 343.2 \\
\hline
\end{tabular}

Then, the signal-to-noise ratio was determined using the ANOVA statistical result analysis. The applied criterion was - the less, the better. The $\mathrm{S} / \mathrm{N}$ ratio was calculated using the formula:

$$
\frac{S}{N}=-10 \cdot \log \left(\frac{1}{n} \sum_{i=1}^{n} y_{i}^{2}\right)
$$


The quadratic equation was formulated to describe the average maximum temperature:

$$
T_{\text {max_avg_alc }}=0.0180174 * v_{c}{ }^{2}-245.926 * f^{2}-1.998 * v_{c}+668.014 * f-5.26 * f * v+300\left[{ }_{c}^{\circ} \mathrm{C}\right]
$$

Table 6 includes the values of the $\mathrm{S} / \mathrm{N}$ ratio, the average maximum temperature $\left(\mathrm{T}_{\text {max avg }}\right)$ and the calculated average maximum temperature $\left(\mathrm{T}_{\text {max _avg_calc }}\right)$ determined using the formula $(2)$.

Table 6. The values of the $\mathrm{S} / \mathrm{N}$ ratio, $\mathrm{T}_{\max \text { avg }}$ and $\mathrm{T}_{\max \text { avg calc }}$

\begin{tabular}{|c|c|c|c|c|c|c|}
\hline $\begin{array}{c}\text { Test } \\
\text { no. }\end{array}$ & $\begin{array}{c}v_{c} \\
{[\mathbf{m} / \mathbf{m i n}]}\end{array}$ & $\begin{array}{c}f \\
{[\mathbf{m m} /} \\
\mathbf{r e v}]\end{array}$ & $\begin{array}{c}a_{p} \\
{[\mathbf{m m}]}\end{array}$ & $\begin{array}{c}T_{\max \text { avg }}\left[{ }^{\circ} \mathbf{C}\right] \\
{[\mathbf{d B}]}\end{array}$ & $\begin{array}{c}S / N \\
{\left[\begin{array}{c}\max \\
{\left[{ }^{\circ} \mathbf{C} \mathbf{C}\right]}\end{array}\right.}\end{array}$ \\
\hline 1 & 60 & 0.048 & 2.77 & 257.0 & -48.1978 & 261.3 \\
\hline 2 & 60 & 0.153 & 2.77 & 306.7 & -49.7308 & 293.1 \\
\hline 3 & 60 & 0.249 & 2.77 & 310.8 & -49.8488 & 317.5 \\
\hline 4 & 100 & 0.048 & 2.77 & 289.6 & -49.2353 & 286.6 \\
\hline 5 & 100 & 0.153 & 2.77 & 288.9 & -49.2121 & 296.3 \\
\hline 6 & 100 & 0.249 & 2.77 & 307.3 & -49.7508 & 300.5 \\
\hline 7 & 140 & 0.048 & 2.77 & 373.3 & -51.4405 & 369.6 \\
\hline 8 & 140 & 0.153 & 2.77 & 353.5 & -50.9681 & 357.2 \\
\hline 9 & 140 & 0.249 & 2.77 & 343.2 & -50.7125 & 341.1 \\
\hline
\end{tabular}

The correlation coefficient value is $\mathrm{R}-\mathrm{Sq}=93.21 \%, \mathrm{R}-\mathrm{Sq}(\mathrm{adj})=72.54 \%$.

The impact of the feed rate and cutting speed on the $T_{\text {max_avg_alc }}$ was determined based on the statistical analysis (Fig.7).

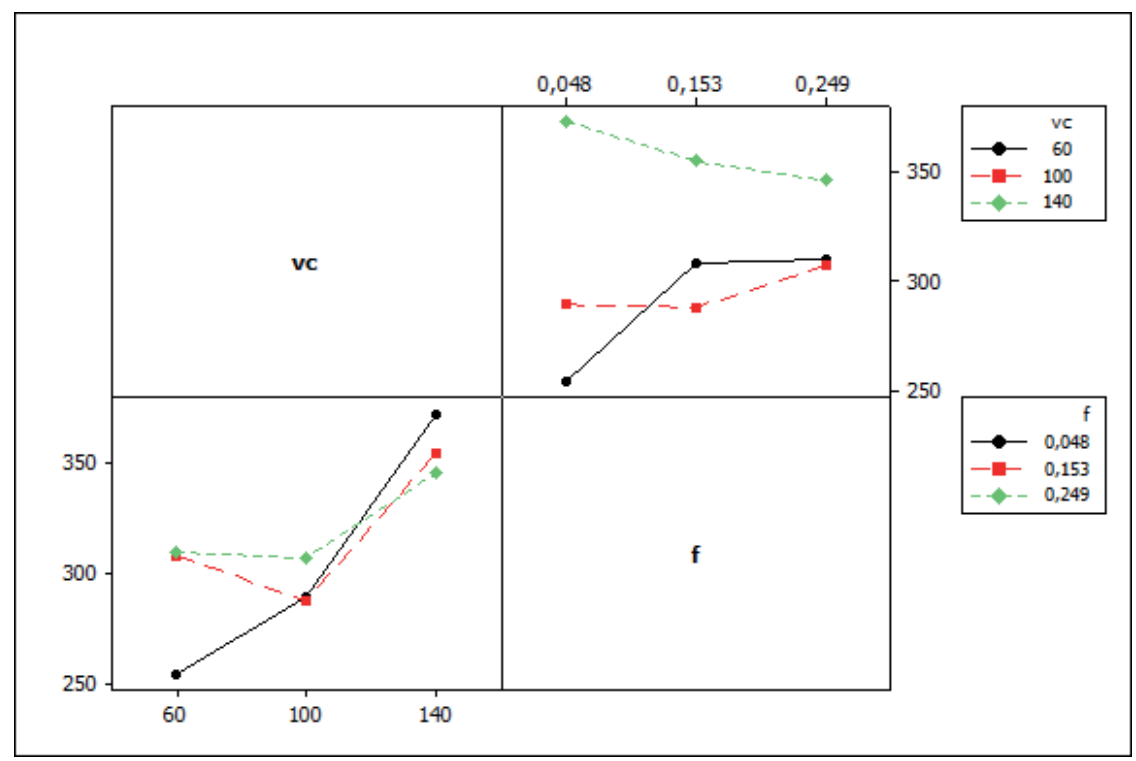

Fig. 7. The impact of the feed rate and cutting speed on the $T_{\text {max avg_alc }}$ 
Below (Fig. 8) is a 3D graph presenting the relationship between the cutting speed, feed rate and the calculated average maximum temperature.

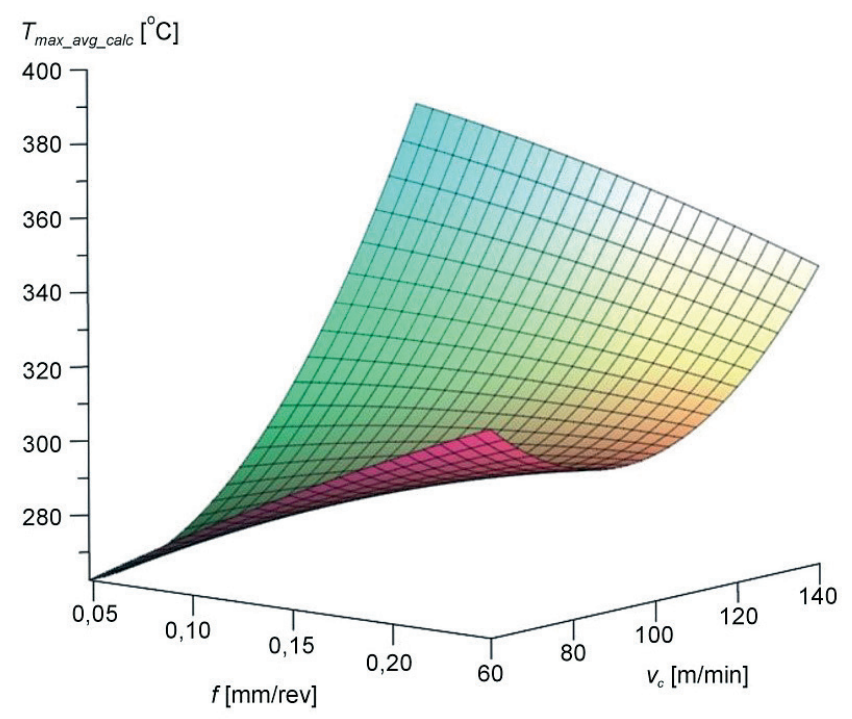

Fig. 8. The relationship between the cutting speed, feed rate and the calculated average maximum temperature

\section{Conclusions}

The graphs obtained based on the regression function $\mathrm{T}_{\max \text { arg calc }}$ allow for a determination of the impact of machining parameters $\left(v_{c}\right.$ and $\left.f\right)$ on the cutting zone temperature. The cutting zone temperature grew as the cutting speed increased for all three feed rate values. The lowest temperature (about $261^{\circ} \mathrm{C}$ ) was recorded for $v_{c}=60 \mathrm{~m} / \mathrm{min}$ and feed rate $f=0.048 \mathrm{~mm} / \mathrm{rev}$. Higher temperatures are observed for faster feed rates $f=0.153$ and $f=0.249$. The obtained trend indicates a temperature increase along with the cutting speed increase. The maximum temperature values of about $340-370{ }^{\circ} \mathrm{C}$ were obtained for $v_{c}=140 \mathrm{~m} / \mathrm{min}$, for three feed rate values. The situation in the case of increasing the feed rate at three cutting speed values is somewhat different. In case of two lower cutting speeds, the temperature grew as the feed rate is increased, although larger differences occur for $v_{c}=60 \mathrm{~m} / \mathrm{min}$. In case of the highest cutting speed, the feed rate increase caused a drop of the recorded average maximum temperature by about $25^{\circ} \mathrm{C}$. A thermal balance model for orthogonal turning can be used to explain the obtained trends describing the temperature value. For a feed rate increase, it can be said that the thermal energy generated in the cutting zone in the form of heat fluxes penetrates between the tool, the chip and the workpiece. In orthogonal turning, the feed rate value is identical with the cut layer thickness. The chip cross section increases, and the energy dissipation is larger. The cutting speed increases results in the higher chip flow speed along the tool face, and this in turn causes a destruction of heat fluxes penetrating between the chip and the tool. 


\section{References}

[1] Chauvy P.F., Madore C., Landolt D., Variable length scale analysis of surface topography: characterization of titanium surfaces for biomedical applications, Surface and Coatings Technology, 1998, 110, 48-56.

[2] Che-Haron C.H., Tool life and surface integrity in turning titanium alloy, Journal of Materials Processing Technology, 2001, 118, 231-237.

[3] Grzesik W., A survey of current knowladge on machining titanium and its alloys, The $5^{\text {th }}$ International Scientific Conference Development of Metal Cutting, 21-26.

[4] Jaspers, S.P.F.C., Dautzenberg, J. H., Taminiau, D. A., Temperature Measurement in Orthogonal Metal Cutting, Int. J Advanced Manufacturing Technology, 14, 1998, 7-12.

[5] Kolahani F., Manoochehri M., Hosseini A., 2011, Application of Taguchi Method and ANOVA Analysis for Simultaneous Optimization of Machining Parameters and Tool Geometry in Turning, World Academy of Science, Engineering and Technology, 74, $82-85$.

[6] Siwiec, J., Obróbka materiałów w stanie utwardzonym, Czasopismo Techniczne, 5-M/2011.

[7] Struzikiewicz, G., Zębala, W., Rumian, K., Application of Taguchi method to optimization of cutting force and temperature during turning of difficult to cut materials, Key Engineering Materials 686, 2016, 114-118.

[8] Ślusarczyk, E., The implementation of a thermal imaging camera for testing the temperature of the cutting zone in turning. Proceedings of 10031, 2016, 100310L1-100310L7.

[9] Ślusarczyk, Ł., Franczyk, E., Development and verification of a measuring stand for recording the physical phenomena during turning, Photonics Applications in Astronomy Communications Industry and High-Energy Physics Experiments Book Series: Proceedings of SPIE 10445, 2017, 104456G.

[10] Zębala, W., Gawlik, J., Matras, A., Struzikiewicz, G., Ślusarczyk, Ł., Research of surface finish during titanium alloy turning, Key Engineering Materials, 581, 2014, 409-414. 